\title{
ПРАВОВЫЕ ОСНОВЫ САМОУПРАВЛЕНИЯ КОРЕННЫХ НАРОДОВ КАНАДЫ
}

\begin{abstract}
Аннотация: Автор подробно рассматривает такие аспекты темы как история борьбы аборигенов Канады за политические права, эволюиию и современные модели их самоуправления. Особое внимание уделяется анализу конституиионно-правовых основ самоуправления, судебной практики. Обсуждается проблема юридического признания аборигенного права, основанного на факте первожительства, и касающегося, прежде всего, владения землями и самоуправления. В предмет исследования входит и изучение положений Индейского акта 1951 г., в соответствие с которым коренные жители получили право самоуправления через советы общин, осуществлено разделение индейцев на «статусных» $и$ «нестатусных». Анализ наиболее значимых аспектов правовых основ самоуправления коренных народов Канады проводился на основе исторического, формальноюридического, сравнительно-правового методов научного исследования. Основной вывод исследования являются положение о том, что коренные народы Канады рассматривают самоуправление и самоопределение как продолжение системы прав, обеспечивающих их жизнедеятельность как особой группы. Международное право и канадское право осуществляют признание права на самоуправление. Переговоры относительно самоуправления в Канаде привели к заключению ряда соглашений, часть из которых имеет конституционную охрану, а другие - иных актов. Различные аборигенные группы представляют самоуправление в различных формах. Для многих первых наиий самоуправление означает возможность правотворчества, в рамках которого может быть скорректировано федеральное право и право провинций. Правительство Канады частично признает самоуправление как правовую возможность общины предоставлять услуги.
\end{abstract}

Ключевые слова: Первые нации, самоуправление, Канада, индейцы, первожительство, конституционные основы, Индейская политика, аборигенное право, самоадминистрирование, аборигены.

Abstract: The author considers in detail aspects such topics as the history of the struggle of the Canadian aborigines for political rights, evolution, and contemporary models of their self-government system. Special attention is given to the analysis of constitutional framework on self-governance, as well as judicial practice in this sphere. The author discusses the problem of legal recognition of aboriginal rights, based on the fact of first settlement, and, above all, ownership of land and self-governance. The subject of this research includes the study of provisions of the Indian act (1951), according to which the indigenous people were given the right to self-governance through community councils, and division of Indians into the "status-holding" and "non-status". Analysis of the most significant aspects of the legal framework of self-governance of aboriginal peoples in Canada was conducted on the basis of historical, formal-legal, comparative legal methods of scientific research. The main conclusion of this research is the proposition that the aboriginal peoples of Canada are considering self-government and self-determination as a continuation of the system of rights that ensure their livelihoods as a special group. International law and Canadian law must recognize the right to self-governance. The negotiations on self-government in Canada led to the conclusion of several agreements, some of which have constitutional protection and other acts. Various aboriginal groups practice the system of self-government in various forms. For many First Nations government means the ability to make law, which can adjust the Canadian federal and provincial law. The Canadian government partially recognizes the self-government as the legal ability of the community to provide services.

Keywords: First nations, self-governance, Canada, Indians, native, constitutional basis, Indian policy, aboriginal law, self-administration, aboriginals.

Введение.

оренные народы, называемые в Канаде «первыми нациями», численность которых по различным оценкам составляет от 2 до 7\% населения страны, рассматривают термин «самоуправление» с учетом различных теоретико-методологических подходов. Для одних народов самоуправление означает возможность осуществления правотворчества в рамках канадского государства. Так, для инуитов Нунавут наибольшее значение имеют договоренности об урегулировании земельных отношений и определении территории, на которой как инуиты, так и не-инуиты могут реализовывать самоуправление. Для других, к примеру, ходеносони, концепция самоуправления представляется продолжением политики колонизации, поскольку существенно ограничивает их суверенитет, ибо их 
устремление связано с обретением самостоятельной государственности. В результате гражданских протестов (2006-2007 гг.) в Каледонии (провинция Онтарио) они добились частичного признания их аборигенного права, в соответствии с которым осуществляется регулирование ряда важных сфер общественных отношений. Поныне многие коренные народы Канады считают, что современная правовая и политическая системы не отражают подлинного признания их самоуправления [7, 8, 11].

На более ранних этапах государственного развития Канады ее политические деятели обосновывали ту точку зрения, в соответствии с которой под самоуправлением понимается только администрирование отдельных видов услуг, предоставленных правительством. Разумеется, такой подход исключал какие-либо права аборигенных народов на правотворчество. С того времени ведется обсуждение сущности «подлинного самоуправления», его отличий от «самоадминистрирования». В отчете Королевской комиссии по Аборигенным Народам (англ. Royal Commission on Aboriginal Peoples) было сформулировано весьма широкое и гибкое определение, предполагающая достаточные возможности для инициатив в сфере самоуправления [7, с. 164]. В статье, руководствуясь историческим, формально-юридическим, сравнительно-правовым методами научного исследования, анализируются наиболее значимые аспекты правовых основ самоуправления коренных народов Канады.

Борьба аборигенов за право на самоуправление. Представители аборигенных народов десятилетия боролись за право на самоуправление, его особое признание в Конституционном акте Канады (1982). На протяжении первых двух веков в отношениях между европейцами и коренными народами сохранялись элементы суверенности и партнерства. На договорной основе власти стремились оформить отчуждение территорий коренных жителей, закрепив за ними особо оговоренные земли. В Королевской прокламации 1763 г. за верховным сувереном признавались исключительные права на приобретение аборигенных земель посредством заключения соглашений с авторитетными представителями племен или групп с последующим их утверждением на собраниях всех членов общин. «Поскольку является справедливым, разумным и важным для наших интересов, а также для безопасности наших колоний, чтобы некоторые нации и племена индейцев, с которыми мы имеем контакт и которые живут под нашей защитой, не обижались и не притеснялись в их правах на владение теми частями нашего доминиона, которые не были уступлены или приобретены нами, эти земли резервируются за индейцами в качестве их охотничьих территорий», - говорилось в прокламации. В конце XVIII в. наблюдался процесс систематического отчуждения земель у аборигенов с одновременным образованием особых районов поселения индейцев - резерваций. Управление индейскими делами перешло в 1830 г. от военных к гражданским властям [5, с. 20-22].

Акт о Британской Северной Америке (1867) закрепила исключительные законодательные полномочия в отношении индейцев и резервированных за ними земель за федеральным парламентом [1]. После образования доминиона Канада с 1871 по 1921 г. стали заключаться индейские договоры (номера с 1 по 11), оформлявшие уступки огромных территорий аборигенов в пользу государства. Позднее некоторые договоры были дополнены включением новых земель. По этим договорам индейцы передавали земли, сохраняя мир и доброе согласие с властями и поселенцами, а власти в свою очередь брали обязательства предоставить им резервации для проживания, преимущества в охоте и трапперстве, денежную и прочую помощь для поддержания хозяйственной жизни, организацию образования. В то же время в пределах границ Канадского доминиона оказались огромные территории, вообще не охваченные договорными обязательствами (субарктические регионы от Ньюфаундленда, Лабрадора и северного Квебека на востоке до Северо-Западных территорий, Юкона и Британской Колумбии на западе).

Принятые в 1876 и 1880 гг. Индейские акты ликвидировали индейское самоуправление, федеральное правительство полностью забрало под свой контроль вопросы социальной службы и образования. В 1951 г. был принят очередной Индейский акт, провозгласивший главной целью государства «интеграцию индейцев в канадское общество» В соответствии с Индейским актом (1951) коренные жители получили право самоуправления через советы общин, закреплено деление на статусных и прочих индейцев («нестатусных») [10]. Только статусные индейцы, зарегистрированные в соответствующем порядке федеральными органами власти (Министерством по индейским делам и развитию Севера), освобождались от налогов на землю и имели право выбирать местные органы в резервациях. Возглавивший в 1968 г. правительство П.Э. Трюдо считал, что все канадцы должны иметь одинаковые права, независимо от их расовых, этнических или религиозных отличий. В «Белой книге по индейской политике» (1969) обосновывались отказ от признания за индейцами исконных прав на землю, отмена специ- 
ального законодательства, упразднение Министерства по делам индейцев с передачей его полномочий провинциальным органам и другим федеральным министерствам. Индейцы выступали решительно против ликвидации резерваций, критиковали правительство за выработку новой политики без их участия и учета рекомендаций своих организаций и общин. В жизнь программа не была проведена, а правительство пошло на ряд уступок. В 1969 г. последняя канадская провинция сняла ограничения на участие индейцев в федеральных выборах. В 1973 г. за нестатусными индейцами было признано право на владение землями при решении в их пользу судебных исков на неохваченные договорами территории [4, с. 7; 5, с. 82-85].

В 1970-е г. впервые был поднят вопрос о юридическом признании аборигенного права, основанном на факте первожительства, и касающегося, прежде всего, владения землями и самоуправления. Историкоправовой интерес представляет «дело нишга» (по названию индейского народа в Британской Колумбии), когда вождь нишга Кэлдер при поддержке адвокатов и ученых сформулировал иск о нарушении договорных обязательств правительством и о праве индейцев на занимаемые ими земли в Британской Колумбии, которые никогда формально не уступались колонизаторам. Суд Британской Колумбии отказался признать за нынешними нишга права на землю на том основании, что их предки к моменту контакта с европейцами были слишком примитивным обществом и не обладали законами, которые английская метрополия была бы способна признать. Однако Верховный суд Канады в 1973 г., пересматривая дело, хотя и отклонил иск по ряду формальных причин, но по сути признал существование особых аборигенных прав. За этим последовали судебные решения по признанию аборигенных прав эскимосов Бейер-Лейк и индейцев кри, живущих у залива Джеймс. В то же время судебные власти всячески старались ограничить признаваемые ими аборигенные права. Так, например, в 1977 г. суд Британской Колумбии постановил, что на индейцев распространяются все законы и правила, регулирующие охоту и трапперство в стране.

В 1973 г. за нестатусными индейцами было признано право на владение землями при решении в их пользу судебных исков на неохваченные договорами территории. Правительство признавало исторически определенные обязательства властей перед индейцами, законность индейских жалоб в отношении выполнения властями условий договоров, которые были заключены еще в ходе колонизации. Власти признали также необходимость учитывать законные права аборигенов на землю, охотничьи и рыбные угодья независимо от условий договоров. Федеральное правительство объявило, что оно готово принять на рассмотрение земельные иски, основанные на исторических правах, и вести по ним переговоры. Соглашения по искам были достигнуты с кри побережья залива Джеймс, с наскапи Шеффервилла и с эскимосами инувиалуит Западной Арктики [5, с. 86-87].

Конституционный акт Канады (1982 г.) в статье 35 «Права коренных народов Канады» закрепил «признание и подтверждение существующих аборигенных и договорных прав коренных народов Канады», определив, что к ним относятся индейцы, эскимосы и метисы (потомки смешанных браков аборигенов и колонистов-неаборигенов). Кроме того, статья 37 предусматривает проведение конституционной конференции с участием премьер-министра страны и первых министров провинций, которая должна обсудить вопрос об определении прав коренного населения и отражении этих прав в тексте конституции. С принятием Конституционного акта было утверждено право аборигенных народов на сохранение и развитие своих культур и право на некоторые формы самоуправления в рамках канадской конституции. Как и ранее заключенные договоры с индейцами, к источникам конституционного права относят и Соглашения по урегулированию земельных требований коренного населения, поскольку в п. 3 ст. 35 Акта о Конституции Канады 1982 г. отмечается, что термин «договорные права» охватывает такие права, которые возникают из уже подписанных соглашений или тех, которые могут быть подписаны в будущем [9].

С 1983 по 1987 г. состоялись четыре министерские конференции с участием лидеров аборигенных организаций, но все они закончились безрезультатно: федеральное правительство и правительства ряда провинций отвергли требования коренного населения закрепить в конституции право на самоопределение и самоуправление, включающее передачу в руки общин и аборигенных организаций политической и законодательной власти. Созданная парламентом в 1983 г. специальная комиссия по индейскому самоуправлению в своем докладе рекомендовала осуществить конституционное закрепление законодательной власти общинных советов в таких сферах, как образование, местное налогообложение, социальное обеспечение и другие, обычно находящихся под юрисдикцией провинциальных правительств [6, с. 229-243]. В 1985 г. были внесены изменения в Индейский акт, устранено дискриминационное для аборигенных женщин положение, по которому они и их дети лишались права сохранять индейский статус и членство в общине в случае вступления в брак с не- 
индейцем, а ранее лишенные статуса по этой причине были в нем восстановлены. В 1990 гг. правительство Канады предприняло попытку расширить модель самоуправления в отношении коренных народов, в частности разработав Шарлоттаунское соглашение, однако предложенные разделы были отклонены на национальном референдуме [7, с. 164-165]. Позитивное политическое значение имело сделанное в 1994 г. заявление от имени Правительства Канады о признании вины перед коренными народами.

\section{Самоуправление как естественное право аборигенов Канады.}

Многие коренные народы Канады рассматривают самоуправление как часть унаследованного от предков суверенитета, неотъемлемую составляющую их этнической идентичности, находящейся под охраной особого правового регулирования, за пределами канадского права, в том числе конституционного. В то же время такое понимание не исключает охрану данного права Конституционным актом Канады [7, с. 164165]. Право на самоуправление интерпретируется как естественное и фундаментальное право аборигенов. Данный подход еще поныне оспаривается в рамках теории на самоуправление как системы делегирования государством части полномочий коренному народу.

В судебной практике имеется прецеденты, в которых право на самоуправление признавалось в качестве естественного права. В книге «Коренные народы, самоуправление и конституция» (Оттава, 1993), изданной Королевской комиссией по коренным народам, описаны судебные разбирательства (1802), связанные с жизнью одного перебравшегося на запад уроженца Квебека Вильяма Коннолли, женившегося на представительнице народа кри Сюзанне. Бракосочетание произошло по законам народа кри, без освящения пастором или регистрации государственным чиновником. После тридцати лет супружества, рождения шестерых детей Вильям вернулся вместе с семьей в Монреаль. Вскоре, однако, он решил считать свое супружество недействительным и женился вновь по католическим канонам на Джулии Вулрих. Все свое имущество он завещал Джулии и их двоим детям. После смерти Вильяма (1862) его старший сын от первого брака Джон Коннолли возбудил иск против Джулии Вулрих на предмет получения своей доли из наследства отца. Этот знаменитый процесс обошел все судебные инстанции и в конце концов принес победу Джону. Суд признал, что бракосочетание по законам кри имеет юридическую силу. В обоснование этого решения суд указал, что, хотя первые подавши- еся на Запад торговцы принесли с собой свои законы, эти территории были давно заселены мощными индейскими племенами, чьи законы и жизненный уклад не были отменены тем фактом, что они начали торговать с английскими и французскими купцами, а, напротив, правительство не вмешивалось ни в индейский внутренний распорядок, ни в самоуправление, и их жизненный уклад продолжал регулироваться их собственными законами [3].

Сформировалась широкая поддержка научной юридической общественности концепции самоуправления как естественного права аборигенов. В числе аргументов в пользу данного подхода следующие: перед тем, как стать европейцами аборигенные народы были организованы как самоуправляемые общины; аборигенные народы были признаны Короной в качестве наций, способных выступать участником соглашений; аборигенные народы не отказывались от права на самоуправление; несмотря на то, что право на самоуправление было существенно ограничено, оно никогда не было упразднено; ограничения права на самоуправление юридически не состоятельны [7, с. 165].

Федеральное правительство решило продолжить развивать тот подход, что аборигенные народы имеют естественное право на самоуправление. Принципы, по которым ведутся переговоры по заключению соглашений в сфере самоуправления, можно изучить по материалам, представленным на сайте Дел Аборигенных Народов и Развития Северной Канады в разделе «Подход Правительства Канады к Реализации и Переговорам Унаследованного Права Аборигенных Народов на Самоуправление», в котором говорится: «Правительство Канады признает естественное право на самоуправление как существующее аборигенное право в соответствии с разделом 35 Конституционного акта 1982 г. Оно признает также, что естественное право может быть выражено в соглашениях и в контексте Отношения Короны к Соглашению с Первыми Нациями. Признание естественного права основано на представлении, что аборигенные народы Канады имеют право управлять самими собой в части внутренних вопросов общин, отражающих их уникальные культуры, идентичности, традиции, языки и институты, и с уважением к их особому отношению к земле и ресурсам» [7, с. 166].

В марте 1985 г. Национальная Ассамблея Квебека приняла резолюцию, призывая к переговорам с Первыми нациями по вопросам, включая самоуправление в рамках Квебека, способствуя их развитию как особых народов, обладающих собственной идентичностью и реализации их прав в Квебеке». Два 
десятилетия спустя в октябре 2007 г. народ кри проголосовал 90\% за принятие Соглашения, касающегося Новых Отношений между Правительством Канады и Кри Ию Истчи. Данное Соглашение о Новых отношениях включает переговорный процесс относительно выработки договоренностей и принятия нормативноправовой базы о национальном правительстве кри, наделенного властными полномочиями, выходящими за пределами действия Акта Кри-наскапи (Квебек). Процесс осуществлялся в рамках трехсторонних отношений с целью заключения Соглашения об Управлении между Канадой, Квебеком и Большим Советом кри (Ию Истчи) и региональными властями Кри, действующих от имени народа Кри, сообществом Кри, общиной Кри и непосредственно народом Кри. Кроме этого, предполагалось, что народ Кри разработает собственную Конституцию, которая вступит в силу после заключения Соглашения об Управлении. Конституция должна была «выражать ценности и убеждения и быть эффективным как основной закон народа Кри» [7, с. 166].

В 1991 г. провинция Онтарио признала, что естественное право на самоуправление первых наций проистекает от Создателя и первоначальной оккупацией земель первых наций. В Согласии о Трансформационной Реформе, подписанной в ноябре 2005 г. провинцией Британская Колумбия, Канадой и Советом вождей, представляющим первые нации Британской Колумбии, которые нацелены на принятие усилий «устранить пробелы в сферах образования, здоровья, жилищного хозяйства и экономических возможностей», правительства признали «значимость самоуправления у первых наций в поддержании здорового жизнеобеспечения общин». Этот акт является одним из результатов Собрания Первых министров в ноябре 2005 г. в городе Келона (Британская Колумбия). После подписания трехстороннего соглашения в Оттаве в результате федеральных выборов произошла смена власти. Вновь избранная партия - Консервативная партия Канады решила не выполнять обязательства встречи в Колоне. Ранее в 2005 г. премьер Британской Колумбии и первые нации Британской Колумбии поддержали тезис «Обновленные Отношения», в рамках которого унаследованные права аборигенных народов закрепляли возможность распоряжения своей землей [7, с. 166].

Многие коренные народы понимают свое право на самоуправление шире, чем оно рассматривается на федеральном и провинциальном уровнях Канады. Наблюдается тенденция, что процессы признания права на самоуправление коренных народов будут происходить в различных регионах Канады, включая и те области, в которых аборигенные народы уже выработали определенные соглашения.

Канадские суды, однако, не выработали единообразной практики закрепляет ли Конституционный акт (1982) права коренных народов на самоуправление. Некоторые низшие суды приняли решение, что такого права у коренных народов нет. Например, один судья из Британской Колумбии посчитал, что право на самоуправление было упразднено. Он отметил, что Конституционный Акт Канады закрепляет только два уровня правотворчества - федеральный и провинциальный. В то же время, имеются и другие решения судов. В деле Кемпбелл против Британской Колумбии (Генерального Прокурора) в 1998 г. был сделан вызов Гордоном Кемпбеллом и другими по обсуждаемому соглашению, в том числе относительно самоуправления, между Племенным Советом Низга, провинцией Британская Колумбия и Канадой. Они отметили, что соглашение является неконституционным и не может вступить в силу. В $200 б$ судья не удовлетворил их требования, в том числе и касающихся Раздела 35(1) Конституционного Акта 1982, определяющую защиту прав на самоуправление [7, с. 167].

В провинции Онтарио было судебное разбирательство, в котором несколько представителей коренных народов с острова Валпол были привлечены к юридической ответственности за охоту за пределами своей резервации на территории относящейся к другому коренному народу по Соглашению Робинсон-Супериор. Апелляционный суд принял решение, в котором отметил, что представители одного коренного народа вправе найти укрытие в рамках Соглашения с другими коренными народами. Это решение соответствовало традициям коренных народов добрососедства, предоставления права другим близким племенам охотиться вместе. Таким образом, Апелляционный суд признал, что представители коренные народов вправе охотиться и за пределами своей резервации, на другой территории коренных народов в случае наличия соответствующего обычая [7, с. 167-168].

Верховный суд Канады оставил вопрос открытым. В 1996 г. в деле Р. против Памаевон в ответ на исковые требования установить существует ли право коренных народов на самоуправление, включающее право регулировать организацию азартных игр, Верховный суд разрешил регулировать этот вопрос, но не установил, что раздел 35(1) включает этот аспект в право на самоуправление. После этого дела, было другое - Делгамуукв против Британской Колумбии о проблеме обозначений на языке коренных народов, в котором судья Лэймер отметил, что «обширная природа исковых требований повлекло невозможность 
сторонам осветить весьма сложные концептуальные вопросы относительно права коренных народов на самоуправление. Степень сложности этой проблемы демонстрирует Отчет Королевской комиссии по Аборигенным народам, в котором 277 страниц посвящено этой теме». Некоторые представители аборигенов требуют в канадских судах установить, что право аборигенных народов должно признаваться в Канаде наравне с общим правом. Суды соглашаются, что мнение коренных народов должно быть учтено наряду с общим правом и сложилось такое представление что подобный «учет» и есть фактически аборигенное право [7, с. 168]. Таким образом, в решении по делу Делгамуукв вопрос о том, может ли право на самоуправление в определенных случаях рассматриваться как конституционное право коренных народов, предусмотренное статьей 35 Конституции, был отложен.

До 1989 г. ООН выстраивала политику на скорейшую ассимиляцию аборигенных народов. В том же году Всемирная организация труда приняла новую конвенцию, в которой были признаны права коренных народов развивать собственные институты, культуры, идентичности в рамках существующих правовых систем народов мира. В этот же период рабочая группа по коренным народам ООН разработала Декларацию прав коренных народов, в одном из первых вариантов которой отмечалось, что «коренные народы имеют право на автономию или самоуправление по вопросам, относящимся их внутренним или местным делам». Статья 3 в итоговом варианте документа, представленного на утверждение Генеральной Ассамблее ООН была сформулирована следующим образом: «Коренные народы имеет право на самоопределение. По природе этого права они свободно определяют свой политический статус и свободно поддерживают свое экономическое, социальное и культурное развитие». Декларация была принята в сентябре 2007 г. [2]. Канада, будучи ключевым участником подготовки Декларации, была в числе четырех стран, проголосовавших против ее принятия. В ноябре 2010 г. Канада ратифицирует Декларацию, но в ограниченных параметрах. Канада отмечает, что соблюдать нормы Декларации желательно, но не обязательно. В связи этим многие проблемы, связанные с самоуправлением, контролем над землей, другими природными ресурсами и др. остались не решенными [7, с. 169].

\section{Современные модели самоуправления у аборигенов Канады.}

Королевская комиссия по аборигенным народам приняла документ, в котором были обсуждены пути выполнения позиций Декларации ООН, в том числе модели организации самоуправления. Было предложено три варианта самоуправления: национальная модель, публичная правительственная модель, модель сообщества интересов. Какая из моделей будет принята - «суверенной ассоциации» с Канадой, та или иная форма самостоятельной государственности, это вопрос будущего [7, с. 169-170].

Национальная модель предполагает пересмотр отношений между государством и коренными народами, расширение числа аборигенных поселений. От 60 до 80 аборигенных народов могут заменить ныне существующую этническую систему разделения на объединения в рамках Индейского акта, сообщества Метисов и Инуитские поселения. Эти аборигенные народы, которые смогут реализовать новую модель самоуправления. При этом согласие правительств не потребуется для аборигенной нации осуществлять свои правомочия в ключевых областях, таких как гражданство, семейные отношения и организация правосудия. Аборигенное право может стать одним из важнейших источников канадского права. Действие аборигенных институтов, однако, существенно ограничено, они не должны пересекаться с другими сообществами и не переходить в сферу компетенции федеральной и провинциальной властей. Это право должно соответствовать Хартии прав и свобод. Существует огромное множество проблем с созданием крупных наций из числа более, чем 630 относительно независимых индийских объединений. Сохранение земли для Метисов за пределами провинции Альберты будет большим вопросом. Деятельность правительственных институтов, во многом характеризующаяся враждебностью и отстраненностью, образуют «большие кочки», которые необходимо перепрыгнуть.

Две другие модели существуют в настоящее время. Оригинальная система самоуправления организована в особой административной единице Северо-Западной Территории - Нунавут (площадь составляет 2 млн. кв. км.). Хотя Инуиты - большинство в Нунавут, их правительства разрешает участие в самоуправлении всех резидентов этой территории, инуитов, не-инуитов. Соглашение о Нунавут ратифицировано парламентом и вступило в силу в 1999 г. [4, с. 22]. Переговоры о самоуправлении и о земельных требованиях эскимосов восточной части Северо-Западной Территории велись не только по вопросу о традиционном управлении, но и вообще о формировании новой территории, в пределах которой проживает более $85 \%$ эскимосов. Проект образования предусматривает выделение образования Нунавута из 
Северо-Западной Территории, составив, наряду с ней и Юконом, третью часть Канады.

В городских районах и сообществах без эксклюзивных земельных баз (резерваций) аборигенные народы вправе оказывать услуги в сфере образования, жилищного хозяйства и других социальных вопросов. Организациям, осуществляющим предоставление услуг, или сеть услуг, как правило, делегируются соответствующие полномочия в порядке, закрепленном федеральным и провинциальным законодательством. Самоуправление не осуществляется в одинаковом объеме у различных групп аборигенных народов, а рассматривается в индивидуальном порядке. Аборигенные сообщества самостоятельно определяют приоритеты и выступают с инициативами.

Законодательство Канады предусматривает учреждение специализированных агентств и институтов. Создание единой организации коренных народов в Канаде представляется весьма затруднительным, поскольку интересы разных групп коренного населения различны. В числе организаций Агентства о заботе над детьми, рожденными в семьях коренных народов, Клиники юридической помощи аборигенным народам, Центры дружбы коренных народов, Ассоциация женщин коренных народов, Национальная корпорация индейских искусств и ремесел, Ассоциация по социально-экономическому развитию резерваций, Совет по образованию индейцев Онтарио, Объединенные Коренные Народы в Британской Колумбии и др. Центры дружбы во многом сориентированы на всестороннюю поддержку городских индейцев. Интересы городских индейцев, эскимосов и метисов представляет Конгресс коренных народов, в прошлом называвшийся Советом туземцев Канады.

Наиболее представительной и влиятельной организаций статусных индейцев Канады является созданная в 1982-1985 гг. Ассамблея первых наций, в общем собрании которой один раз в год участвуют вожди 607 общин страны. В промежутках между общими собраниями организацию возглавляет Конфедерация Народов, созываемая четыре раза в год и включающая по одному представителю регионов (Британская Колумбия; Альберта; Саскачеван; Манитоба; Онтарио; Квебек и Лабрадор; Новая Шотландия и Ньюфаундленд; Нью-Брансуик и Остров Принца Эдварда; Северо-Западная Территория; Юкон), а также еще одного человека на каждые 10000 индейцев в каждом из них. В исполнительный комитет входят национальный вождь, региональные вожди и председатель совета старейшин. Национального вождя, престиж которого очень высок, выбирает общее собрание на три года, региональные вожди избираются вождями своих регионов. Национальным вождем в настоящее время является уроженец Манитобы индеец-кри Овид Меркреди.

В провинциях Саскачеван и Манитоба, а также территории Юкон учреждены подобные организации (в Саскачеване, например, Федерация индейских народов Саскачевана), в которых решения принимаются собранием, включающим вождей всех общин провинции. Община вправе участвовать в нескольких организациях, что иногда создает государственной власти затруднения в поиске правильного партнера для переговоров при решении каких-либо местных проблем. Например, в Альберте действуют две организации: «Индейская Ассоциация Альберты»и «Вожди Альберты». В Онтарио насчитывается четыре объединения: «Союз Нишнавбе-Аски», «Организация Договора № 3», «Союз Индейцев Онтарио». В ареале проживания индейцев на основе доконфедерационных договоров действует «Ассоциация ирокезов и объединенных индейцев». В Квебеке действует организация «Народ Дене».

У эскимосов в 1971 г. была учреждена организация - Инуит Тапирисат, представляющая 35000 аборигенов, проживающих в общинах Юкона, Северо-Западной Территории, северного Квебека и Лабрадора. У Тапирисата восемь членских организаций, семь из которых являются окружными и восьмая - женская. В ближайшие годы семь эскимосских регионов могут быть укрупнены, образовав четыре округа, границы которых совпадут с границами четырех больших земельных требований: Инувиалуит, Нунавут, Северный Квебек и Лабрадор. Президент Тапирисата избирается на прямых выборах всеми эскимосами Канады, достигшими 18 лет. В настоящее время президентом является уроженка региона Инувиалуит Розмари Куптана. В совет директоров Тапирисата входят главы всех членских организаций. Ежегодно созывается съезд, на котором представлены все общины на основании соответствующих квот является также представителем канадских эскимосов во всемирной эскимосской организации. Эскимосская Заполярная Конференция, объединяющая эскимосов четырех стран: США (эскимосы Аляски), Дании (эскимосы Гренландии), России (эскимосы Чукотки) и Канады.

Другой аборигенной организацией является Национальный Совет метисов, формируемый провинциальными организациями Альберты, Манитобы, Саскачевана, Британской Колумбии, Онтарио, представительства которых избираются путем прямых выборов. Действующий президент Национального Совета - уроженец Саскачевана Джеральд Морэн. 
Система самоуправления метисов образуется сложной комбинацией прямых выборов и делегирования с целью уравновешивания интересов представительств разных уровней. Избирателями являются члены общины, достигшие 18 лет [12].

\section{Самоуправление в соответствии с Индейским актом (1951).}

В современный период большинство коренных народов практикуют самоуправление в соответствии с Индейским актом (1951). По-прежнему практикуется разделение на «статусных индейцев» (англ. Status Indians), наделенных льготами и правами в полном объеме в сферах налогообложения, медицинского обслуживания, образования, строительства, благоустройства и др., и «нестатусных индейцев» (англ. Non-Status Indians), которые таковыми не обладают. «Статусные индейцы» формируют «племена» или «общины», которых зарегистрировано в стране более шестисот. Члены общин, главным образом, проживают на территориях резерваций. Резервации нередко рассматривают в контексте изоляции от канадского общества, в то же время их организация стала фундаментальной основой жизнеобеспечения, гарантом сохранения уникальности.

В контексте самоуправления территории разделяются на следующие группы: резервация; земельная собственность общины, на которую режим резервации не распространен; договорная или охваченная земельным требованием территория. В резервации право на самоуправление осуществляется наиболее полно: община сама устанавливает большинство общеобязательных прав, кроме, например, положений уголовного права (так, община не может считать уголовно наказуемым деяние, которое не является наказуемым по законам Канады). Во втором случае вправе устанавливать более строгие, в отличие от действующих повсюду, требования в сфере охраны окружающей среды. В третьем случае община участвует в вынесении решений по вопросам местной экономики. Если какая-то компания желает основать на этой территории новое предприятие, то проводятся многосторонние переговоры, в ходе которых коренные народы стремятся прежде всего ограничить деятельность, вредящую окружающей среде, чтобы мог сохраниться их традиционный образ жизни, а также обеспечить трудовую занятость коренного народа на данном предприятии и при возможности ввести общину в число акционеров.

Общины самостоятельно формируют свои органы управления, прежде всего в лице вождя и советов. Например, у ирокезов, имеющих древний и сложный общественный распорядок, ныне действует две системы вождей: по Индейскому акту и традиционная. Традиционные вожди по-прежнему собираются у больших костров на совещания, где от каждого из шести объединенных народов своя четкая представительная квота. Отказу от системы вождей, установленной Индейским актом, препятствует то, что традиционная система не отвечает жизни в резервациях и общинах и не учитывает ни провинциальных, ни государственных границ между Канадой и США. Традиционная система построена по объединенным народам и родам, но они все же проживают в разных резервациях по ту и другую сторону границы, в то же время есть резервации, где живут члены различных ирокезских народов. Государственная власть контактирует только с вождями, избранными на основании Индейского акта, а в традиционном жизненном укладе ирокезов авторитет традиционных вождей выше.

В большинстве случаев община регулирует круг своих членов, но членство само по себе не означает получения статуса индейца. Регулирование конкретных жизненных сфер делегируется аборигенам соответствующей федеральной, провинциальной, местной инстанцией, в чью компетенцию они входят. Например, большинство резерваций провинции Онтарио имеют свою полицию, обладающей теми же правами, как и провинциальная, в том числе по отношению к находящемуся в резервации нетуземцу, а вне резервации более ограничены. Делегирование осуществляется по договоренностям с каждой общиной в индивидуальном порядке. В ряде провинций судебная власть тоже частично делегирована общине, в части назначения наказаний. После того, как судом присяжных вынесен обвинительный приговор, меру наказания определяет община, или судья по ее предложению. Обычно, в случае незначительного проступка тюремному заключению предпочитают общественно-полезные работы под присмотром общины. Бывали случаи, когда по обвинению в изнасиловании ссылали на год на одинокий необитаемый остров.

В одной из провинций делегирование судебной власти было прекращено под нажимом туземных борцов за женские права. По утверждению представителей женских организаций, подобная практика благоприятствует дискриминации: мужчины, из которых преимущественно состоит общинный совет, не склонны достаточно жестко карать насильников, неплательщиков алиментов и подобного рода нарушителей. В некоторых резервациях есть свои мировые судьи. При данном подходе к организации самоуправ- 
ления вопрос о делегировании полномочий решается индивидуально в каждом отдельном случае.

Случается, когда общине не хватает квалифицированных чиновников для выполнения различных функций или их содержание представляется нецелесообразным, то для выполнения тех или иных конкретных функций могут быть сформированы общие административные в рамках объединения общин. Ярким примером служит Управление образования оджибвеев озера Рейни с местонахождением в Фандер Бэй, созданное общинами десяти резерваций Онтарио, в отношении которых действует договор номер 3. Общины Канады сами решают порядок финансирования подобных институтов. В создании подобных объединений позитивный опыт накоплен в провинциях Манитоба и Саскачеван, в которых общепровинциальная индейская представительская организация комплексно берет на себя устройство всех жизненных сфер. Например, в Саскачеване для этого создана организация, объединяющая всех индейцев этой провинции, со своим парламентом и правительством. Государственные органы Канады взаимодействуют с аборигенными институтами непосредственно.

Финансирование общины, как правило, осуществляется из федерального бюджета и рассчитано на индейцев со статусом, проживающих в резервациях. Единственное исключение составляет университетское образование аборигенных студентов, предоставляемое независимо от проживания в резервации индейца со статусом. Государство оказывает поддержку аборигенам при получении ими всех уровней образования. Финансируются не только общины, но и их объединения (родовые советы).

Эскимосское общество состоит из общин, в числе которых 55 крупных и от 6 до 9 их региональных групп. Община осуществляет признание идентичности эскимоса, руководствуясь комплексом критериев, прежде всего, происхождением. Дляя установления происхождения в одних провинциях достаточно четверти эскимосской крови, а в других требуется полукровность. В то же время община свободно может принять лицо неэскимосского происхождения в качестве почетного эскимоса. Повседневной жизнью руководит совет общины, избираемый всеми ее членами в соответствии с нормами обычного права.

Единственным народом, обладающим правом нормотворчества, являются метисы, осуществляющие свою деятельность посредством советов поселений в Альберте [7]. В то же время правовое положение метисов, в сравнении с другими коренными народами Канады, более неопределенно и запутано. Будучи признаны Конституционным актом (1982) в качестве коренного народа наравне с индейцами и эскимосами, они должны иметь аналогичный комплекс прав, но на практике это не применяется. В отличие от эскимосов, Министерство по индейским делам метисами не занимается, при выделении средств из федерального бюджета их чаще всего не учитывают.

Права коренных народов применяются к метисам лишь в единичных случаях, да и то непоследовательно. Порой провинциальное правительство идет им навстречу, как, скажем, в Альберте, где метисам провинция разрешила создавать поселения, подобные резервациям, но при этом они лишены, например, права охотиться вне этих поселений. В тех случаях, когда на какой-то определенной территории они принимали участие в переговорах об общих земельных требованиях, это происходило только благодаря тому, что метисы живут там вместе с индейцами. Например, такова ситуация с общим требованием в округе Сахту в Северо-Западной территории при заключении Соглашения о земельных требованиях с народами Сахту, Дене и Метисами. Договорные права есть только у тех отдельных общин, которые в свое время присоединились к договору и охвачены сейчас договорным процессом. Главная цель метисов состоит в том, чтобы добиться равного положения с другими коренными народами, в том числе по установлению непосредственного сотрудничества с федеральным правительством. Метисы самостоятельно ведут свой «регистр метисов» по общинам. Община осуществляет признание человека в качестве метиса, руководствуясь информацией о его происхождении и этническом самосознании. Отказ общиной признать кого-либо метисом может быть оспорен в судебном порядке, а также обращением в соответствующую провинциальную организацию. На основе метисского свидетельства предоставляется право передвижения и участия в выборах аборигенных организаций.

\section{Соглашения о самоуправлении.}

В отдельных случаях (Объединения Сишельт, Вестбанк, Джеймс Бэй и Соглашение Северного Квебека) договорились о выходе из правового регулирования в соответствии с Индейским актом. У них самостоятельный правовой статус, они обладают самостоятельностью в ряде сфер общественных отношений. В провинции Юкон были заключены соглашения о самоуправлении, 11 аборигенных народов в настоящее время активно реализуют свои полномочия. Почти все инуиты в Канаде регулируют существенную часть организации своих сообществ в 
соответствии с земельными соглашениями и договоренностями по самоуправлению.

Существенным подходом к регулированию самоуправления является заключение соглашения о самоуправлении между федеральным правительством и коренными народами, в лице отдельной общины, либо объединения общин. В рамках соглашения предусматриваются особенности управления общиной и членство в ней, распоряжение землей, другими природными богатствами, финансами, обеспечение правопорядка, способы разрешения споров, перечень льгот, система финансирования со стороны государства и др. Соглашения должны быть ратифицированы федеральным парламентом и утвержден общиной, после его вступления в юридическую силу в отношении конкретного коренного народа Индейский акт перестает действовать.

Первое соглашение было заключено в 1986 г. с одиночной общиной Сишельт, расположенной в Британской Колумбии. Важнейшей позицией этого акта являлась передача государством коренному народу права собственности на землю. Было подписано соглашение с народами кри и наскапи в Квебеке и индейцами Юкона, ведутся переговоры еще о двадцати соглашениях. В провинции Манитоба в конце 1994 г. было подписано соглашение, по которому федеральные власти передали компетенцию в отношении коренных народов от провинциальных управлений Министерства по индейским делам представительской организации индейцев Манитобы. После того, как подписано соглашение о самоуправлении, правительство уже не делает никаких предписаний об использовании финансов.

До самого последнего времени переговоры о самоуправлении разделяли с переговорами об общих земельных требованиях. Так, с индейцами Юкона переговоры о самоуправлении и земельных требованиях велись хотя и одновременно, но формально были разделены. Жизнь внутри общины, в том числе порядок принятия новых членов, в целом регулируется сегодня уставом общины. Устав принимается самой общиной, но если он будет противоречить Индейскому акту или другим законам, то министр по индейским делам может его аннулировать. Однако после того, как община заключит соглашение о самоуправлении, министр такого права больше не имеет и если, например, община установит положение, противоречащее конституции или правам человека, то аннулировать его можно лишь в судебном порядке.

Наблюдается процесс выхода общин из сферы действия Индейского акта в том, что касается процедуры выборов вождя или совета общины. По своей инициативе они могут отвергать установленные в
Индейском акте процедурные правила и перейти еще до заключения соглашения о самоуправлении на традиционную систему выборов в соответствии с обычным правом. На сегодняшний это сделала половина из 607 общин Канады.

\section{Выводы.}

Канада - государство, активно реализующее современные подходы к сохранению и развитию этнического многообразия. По Конституционному акту Канады (1982) к коренным народам относят «нации индейцев, инуитов и метисов», которые, являясь «первыми нациями» вправе осуществлять отдельные права, поскольку они являются потомками людей, населявших земли этой страны «с незапамятных времен». Важнейшими достижениями в области обеспечения прав коренных народов являются формирование резерваций как основы жизнеобеспечения, предоставление прав не только на землю, но и другие природные ресурсы, создание аборигенных корпораций, представительств и др. Опыт Канады, по ряду политикоправовых аспектов сходных с Российской Федерацией, представляет научно-практический интерес для выработки наиболее адекватной модели правового регулирования положения коренных народов.

Первоначально власти Канады предполагали, что «примитивные» институты и образ жизни аборигенов должны неминуемо трансформироваться, обретая черты евроканадского общества. В последующем государственные подходы изменились. Стремясь к урегулированию взаимоотношений с коренными народами, федеральное правительство в настоящее время стало осуществлять политику, направленную на содействие сохранению и развитию самобытности коренных народов, в том числе выраженной в самоуправлении.

Самоуправление реализуется в различных формах и рассматривается в контексте партнерства как признание естественных прав. Именно самоуправление дает коренным народам возможность осуществлять более широкий контроль и ответственность во всем, что затрагивает жизнь их городов и поселений. Коренные жители стали признаваться особыми общностями, обладающими отличительностью и самосознанием, ведущим как традиционный и современный образ жизни. В Индейском акте подробно регулировался процесс обретения статуса индейца, закреплены процедуры избрания живущей в резервации общиной своего вождя. Ныне в резервациях индейцы самостоятельно регулируют многие жизненные сферы, в числе которых здравоохранение, благоустройство, наблюдение за общественным порядком, формирование инфраструктуры, образование и др. 


\section{Библиография:}

1. Акт о Британской Северной Америке 1867 г. // Конституции государств американского континента / Под ред. Г. С. Гурвича. М., 1959. 525 с.

2. Декларация Организации Объединенных Наций о правах коренных народов. Принята Резолюцией 61/295 Генеральной Ассамблеи от 13.09.2007 // http:/www.un.org

3. Кингсберри Б. Коренные народы Черепашьего острова. Правовое положение и организация коренных народов Канады. Права собственности коренного населения // http.://www.brights.ru/text/inter/68/Chapter7.htm

4. Лопуленко Н.А. Опыт автономии в Канадской Арктике-Нунавут. Серия «Исследования по прикладной и неотложной этнологии» Института этнологии и антропологии РАН. Документ № 170. М., 2004. 35 с.

5. Стельмах В.Г., Тишков В.А., Чешко С.В. Тропою слез и надежд. Книга о современных индейцах США и Канады. М.: Мысль, 1990. 316 с.

6. Юдин В. И. Механизмы обеспечения социокультурной самобытности коренного населения (на примере Канады) // Этносоциум. № 5 (37). 2011. С. 229-243.

7. Aboriginal law handbook. 4th edition. Toronto: Carswell, 2012. $701 \mathrm{p}$.

8. Boldt M. Surviving as Indians: The Challenge of Self-Government. Toronto: University of Toronto Press, 1993.384 p.

9. The Canadian Constitution 1981. La Constitution Canadienne 1981//A Resolution adopted by the Parliament of Canada. Dec. 1981. Ottawa, 1981.URL: http:// canadahistory.com>sections...the_constitution.htm

10. The Indian Act 1951 // URL: http:// indigenousfoundations.arts.ubc.ca

11. Yale D. Belanger, ed. Aboriginal Self-government in Canada: Current Trends and Issues, 3rd. ed. Saskatoon: Purich Publishing, 2008.

12. http://www.suri.ee/muud/kama.html

13. http://www.ubcic.bc.ca

14. Липинский Д.А. Social Bases of Positive Responsibility // SENTENTIA. European Journal of Humanities and Social Sciences. - 2015. - 3. - C. 41 - 69. DOI: 10.7256/1339-3057.2015.3.16009. URL: http://www.e-notabene.ru/psen/article_16009.html

\section{References (transliterated):}

1. Kingsberri B. Korennye narody Cherepash'ego ostrova. Pravovoe polozhenie i organizatsiya korennykh narodov Kanady. Prava sobstvennosti korennogo naseleniya // http.://www.brights.ru/text/inter/68/Chapter7.htm

2. Lopulenko N.A. Opyt avtonomii v Kanadskoi Arktike - Nunavut. Seriya «Issledovaniya po prikladnoi i neotlozhnoi etnologii» Instituta etnologii i antropologii RAN. Dokument № 170. M., 2004. 35 s.

3. Stel'makh V.G., Tishkov V.A., Cheshko S.V. Tropoyu slez i nadezhd. Kniga o sovremennykh indeitsakh SShA i Kanady. M.: Mysl', 1990. $316 \mathrm{~s}$.

4. Yudin V. I. Mekhanizmy obespecheniya sotsiokul'turnoi samobytnosti korennogo naseleniya (na primere Kanady) // Etnosotsium. № 5 (37). 2011. S. 229-243.

5. Boldt M. Surviving as Indians: The Challenge of Self-Government. Toronto: University of Toronto Press, 1993.384 p.

6. Yale D. Belanger, ed. Aboriginal Self-government in Canada: Current Trends and Issues, 3rd. ed. Saskatoon: Purich Publishing, 2008.

7. Lipinskii D.A. Social Bases of Positive Responsibility // SENTENTIA. European Journal of Humanities and Social Sciences. - 2015. - 3. - C. 41 - 69. DOI: 10.7256/1339-3057.2015.3.16009. URL: http://www.e-notabene.ru/psen/article_16009.html 